Purdue University Purdue e-Pubs

$1-1-1975$

\title{
Processing Remotely Sensed Data for Dimensional Analysis
}

T.L. Cox

H. C. Hitchcock

S. G. Weber

Follow this and additional works at: http://docs.lib.purdue.edu/lars_symp

Cox, T. L.; Hitchcock, H. C.; and Weber, S. G., "Processing Remotely Sensed Data for Dimensional Analysis" (1975). LARS Symposia. Paper 48.

http://docs.lib.purdue.edu/lars_symp/48

This document has been made available through Purdue e-Pubs, a service of the Purdue University Libraries. Please contact epubs@purdue.edu for additional information. 
Reprinted from

Symposium on

\title{
Machine Processing of Remotely Sensed Data
}

\author{
June 3 - 5, 1975 \\ The Laboratory for Applications of \\ Remote Sensing \\ Purdue University \\ West Lafayette \\ Indiana \\ IEEE Catalog No. \\ 75CH1009-0 -C \\ Copyright (C) 1975 IEEE
}

The Institute of Electrical and Electronics Engineers, Inc.

Copyright (C) 2004 IEEE. This material is provided with permission of the IEEE. Such permission of the IEEE does not in any way imply IEEE endorsement of any of the products or services of the Purdue Research Foundation/University. Internal or personal use of this material is permitted. However, permission to reprint/republish this material for advertising or promotional purposes or for creating new collective works for resale or redistribution must be obtained from the IEEE by writing to pubs-permissions@iee.org.

By choosing to view this document, you agree to all provisions of the copyright laws protecting it. 
PROCESSING REMOTELY SENSED DATA FOR DIMENSIONAL ANALYSIS ${ }^{1}$

\author{
T. L. Cox, H. C. Hitchcock, and S. G. Weber \\ Tennessee Valley Authority \\ Division of Forestry, Fisheries, and Wildlife Development \\ Norris, Tennessee
}

\begin{abstract}
Forest inventory data was interpreted from color IR photography, transferred to base maps, and digitized for machine processing. The data was registered to geodetic coordinates providing the capability to perform several types of dimensional analysis. Processing data by this technique allowed: (1) Spatial or single variable analysis, (2) overlay or composite analysis (in combination with other variables), and (3) temporal analysis. Information derived from this procedure was input for a land management decision system used to construct a forest management plan for 25,000 acres in east Tennessee.
\end{abstract}

\section{INTRODUCTION}

Multiple-use forest management makes it necessary to consider a number of possible uses in the planning process. Consequently, resource inventories are needed in the decision-making process so resource allocation can reflect varying and often conflicting uses.

An effective forest resource inventory should provide: (1) Information for areal summaries, (2) site-specific information, and (3) spatially distributed and geodetically registered information for dimensional analyses. Remote sensing has traditionally proven a valuable tool in providing information for areal summaries; moreover, new machine processing techniques are greatly enhancing the capabilities for providing site-specific forest resource information and delineating homogeneous management units and identifying areas of conflict(s).

\section{DIMENSIONAL ANALYSIS}

The potential of remotely sensed and other data can be further realized only when the information is keyed to a specific ground location, in other words, when it is registered. Data registration permits overlay of spatial information as we11 as temporal analysis. Overlay analysis of spatial inventory data considers several resources and their relationships. Only when a forest resource is viewed in relation to other resources is the full implication of its manipulation realized. The temporal dimension permits the analysis of the effects of management or land-use change over time.

Machine processing of remotely sensed data for dimensional analysis is an integral part of the Tennessee Valley Authority's analysis systems. This report discusses the use of remotely sensed data and how it is registered to ground locations for dimensional analysis.

TVA LANDS

Lands owned by TVA extend from southwest Virginia and western North Carolina to western Tennessee and Kentucky. These lands fall in six. physiographic provinces and include a wide range of terrain, vegetation, soil types, and land uses.

\section{ANALYSIS TOOLS}

In order to meet management objectives on these lands, TVA's Division of Forestry, Fisheries, and Wildlife Development is utilizing various types of spatial analysis tools to provide additional information. Two of the systems pertinent to

1. Research sponsored in part by the National Science Foundation RANN program under Union Carbide Corporation's contract with the U. S. Atomic Energy Commission, Oak Ridge National Laboratory. 
this discussion are (1) the Land Management Decision System and (2) the Bioterrain Analysis System.

The Land Management Decision System is a decisionmaking process designed for land holdings where sitespecific tradeoffs and activities must be evaluated; it is particularly applicable where multiple-use objectives must be met. A necessary part of this system is an information and analysis system-the Bioterrain Analysis System--that facilitates the analysis and display of spatial data. The objective is rapid processing and analysis of spatial data utilizing flexible computer systems and simple, economical techniques. The processing structure adapted for utilization in spatial analysis efforts provides capabilities for dimensional analysis.

\section{APPLICATIONS}

The Division of Forestry, Fisheries, and Wildlife Development has utilized remotely sensed data in several studies related to land management. Research emphasis has been in three areas :

1. Processing and registration of remotely sensed data for dimensional analyses.

2. Development of analysis techniques using remotely sensed data in combination (overlayed) with other geographic information (e.g. , soil, slope, etc.).

3. Evaluation of study areas to identify management conflicts and to designate land-use potentials.

\section{MATERIALS AND METHODS}

\section{USE OF REMOTELY SENSED DATA}

Data from several sources of imagery have been utilized in analysis of forest resources. Color IR imagery at several scales, black and white at several scales, and ERTS imagery have been used. This discussion is confined primarily to two major sources of remotely sensed data to illustrate the processing for registration.

Medium Scale Color IR Imagery A major source of information for forest resources was 1:24,000 color IR imagery provided by NASA (Marshall Space Flight Center) Environmental Applications
Office. This imagery data was used to construct a multiuse management plan for Norris Reservoir lands. TVA owns about 25,000 acres of 1 and adjacent to the reservoir. Medium scale color IR imagery was used initially to delineate cover types for a 121,000-hectare (300,000-acre) area. Nine cover types were identified on the imagery. Forest stands were delineated on TVA property within the total study area. Stand sizes and volume per acre of the stands were estimated photogrammetrically. A crown diameter scale, a crown cover scale, and a parallax bar were used on nine-inch stereo-pairs of the area to provide this forest resource information (Cox and Weber, 1975). Stand data were then transferred to 7.5-minute topographic quadrangles for registration and digitization.

\section{Other Imagery Data}

Another source of forest resource data used in temporal analysis was I:120,000 color IR imagery for the 7.5minute Clinton, Tennessee, quadrangle. Interpretation was carried out by the Maps and Surveys Branch of TVA's Division of Water Control Planning (Stevens, 1973).

A land cover map of the Clinton quadrangle was prepared from $1: 120,000$ color imagery obtained by the NASA RB57F aircraft in April 1972. Imagery was interpreted using a Kelsh stereoplotter and classified with slight modification according to the Level II land-use classification suggested by the U. S. Department of the Interior (Anderson, et al., 1972). Interpretive methodology applied to another map base is presented by Stevens (1973).

\section{OTHER DATA}

Cover

Cover data for the 7.5-minute Clinton quadrangle were obtained for 1940,1972 , and predicted for 1987. The source of the 1972 Clinton land cover data has been discussed. The 1940 cover data were obtained from intensive field surveys conducted in the entire Tennessee Valley watershed area by TVA in 1939-40. Forest cover was delineated on the 1936 base map for the Clinton quadrangle. Data for 1987 were predicted using a Markov chain technique and a land-use model described by McCarthy, et al., (1974).

Terrain Features

Data for terrain features such as slope, aspect, and other topographic characteristics were obtained for Norris Reservoir by manual interpretations of the appropriate 7.5-minute topographic quadrangle sheets. Slope was estimated 
by counting the number of countour lines falling within the width of the cell used.

\section{INVENTORY METHOD FOR DIMENS IONAL ANALYSES}

The primary purpose of an inventory is to obtain maximum information from a minimum of input data. Therefore, variable selection and limitations are important steps in an inventory. The type of variables and the levels of each variable change depending on the analysis effort.

The methodology discussed applies to both remotely sensed data and terrain characteristics and is heavily oriented toward transferring information to geodetically registered map bases.

\section{Concept}

Classifying lands according to limitations and values provides information needed for the planning process in a dynamic sense. Classification allows the study of relation within and among spatial units. To accomplish the inventory, the following require consideration:

1. Data availability. (time constraints)

2. Data compatibility (computer)

3. Data registration (reference system)

4. Data resolution (varies with needs )

Data availability regulates any analysis. Therefore, remotely sensed data forms an integral sector of all analysis efforts. Spatial data collection efforts were directed toward obtaining data that could be readily analyzed by existing or modified techniques.

only data compatible to resolution needs of the objectives and analysis capability of the processing system were collected. This resulted in using a cellular data bank with each entry represented by references. Collection was based on the dominant feature of the cell size of interest with certain exceptions; these exceptions noted data on occurrence in cells.

An important part of the computerbased spatial analysis is the reference system used to relate a specific point to its datum, to other points, or to other datum at the same point, thereby providing information that enhances a manager's perspective of a resource problem. The geodetic reference system of latitude and longitude was selected as the most readily adaptable standard coordinate system. All remotely sensed data and other geographic information were referenced using this system.

In addition to location, a certain resolution of data is necessary for spatial analysis. Application of a grid to a data source subdivides it in units called cells that reflect the resolution of the sampling effort. Cells of 1.09 , 4.33 , and 17.33 hectares $(2.68,10.7$, and 42.8 acres) have been utilized depending on the resolution needs dictated by the management objectives. Datum for each cell was collected on the basis of the dominant feature of that cell.

Data Collection and Registration AlI remotely sensed and geographic data were transferred to 7.5-minute topographic quadrangle map sheets to ensure proper geodetic registration. Data were then transferred from the quadrangle to transparent mylar overlays consisting of a matrix of cells. Initial numbering of the matrix began in the lower right hand corner. Each mylar was prepared to fit the proper latitude to discount cell size variation from south to north. A map code located each quadrangle by latitude, longitude, and the corresponding row and column within the degree. Grid overlay for digitization was prepared by GRIDOT (Durfee, in preparation).

\section{RESULTS AND DISCUSSION}

The registration of remotely sensed data and other geographical data permitted three types of spatial analyses: (1) Single variable analysis, (2) overlay or composite analysis, and (3) temporal analysis. General inventory estimates of forest resource characteristics (cover, stand volume, etc.) were provided by each analysis and displayed by computer maps. A11 analysis efforts were at 4.33 -hectare $(10.72$-acre) resolution except where noted.

\section{SINGLE VARIABLE ANALYSIS}

Remotely sensed data provided forest and nonforest cover information for 121,000 hectares $(300,000$ acres) in east Tennessee. A printer output and acreage summary was provided to evaluate forest cover patterns and to determine the proportions of forest resources in each cover class. Data were stored at the 4.33-hectare (10.72-acre) level. 
Evaluation of this single variable map and accompanying statistical information provided basic information not previously observed. For example, large contiguous blocks of forests or other cover types were noted, and recommendations for openings ("edge" for wildlife) were suggested. Similar maps were prepared for other forest resource variables such as stand size and volume. Single variable analysis provides a quick look at the geographic distribution of each variable and its statistical information

(Figure 1). These data (any or all levels of the variable) can also be used in combination with other remotely sensed or geographic data for the same area since all data are registered.

\section{OVERLAY ANALYSIS}

Forest resource information at the 4.33-hectare (10.72-acre) level was analyzed by overlay techniques to delineate management units and evaluate selected areas under TVA ownership. Variables were analyzed in various combinations to provide areal summaries and computer maps of the resource categories. For example, a map of forest and nonforest cover types was prepared by delineating only the cover type categories that fell within cells occurring on TVA property. These maps aided land managers by providing information necessary for timber and wildlife management decisions on TVA lands.

Another analysis (overlaying cover and volume classes) provided a breakdown of forest volume classes by each of four forest cover types. Timber volume estimates were provided to inventory the total in each volume class and cover category. The data were limited to TVA property by searching only those cells falling within this ownership category. Overlay analysis located and identified a variety of forest stand volumes capable of sustaining adequate yields of selected forest products. Stand volumes were also needed for wildlife management because mast production, nesting habitat, and other wildlife requirements are related to timber volume classes.

Overlay analysis can be helpful in evaluating forest resources in selected areas and identifying possible management problems. Four variables (ownership, forest cover type, timber volume in bd. ft./acre, and slope) were combined to analyze a forested area adjacent to Norris Reservoir. The map provided the distribution of medium-to-heavy hardwood sawtimber (i.e., estimated greater than 4,000 bd. ft./acre) in five slope classes on TVA property (Figure 2). Data such as these aid in determining harvest operation techniques appropriate for this area. About 10 percent of the merchantable timber is on slopes greater than 58 percent and might be considered inoperable by conventional techniques. Special considerations might be necessary for stands on I slopes greater than 40 percent depending on the underlying soil characteristics. Cell size in this analysis was 1.09 hectares ( 2.68 acres).

These types of analyses are possible because the remotely sensed forest resource and other information were registered to identical areas. Processing of data by this methodology provides temporal analysis also.

\section{TEMPORAL ANALYSIS}

Data referenced to coordinates enables analysis over time. This provides a means for monitoring effects of past land-use changes on forest resources; it also provides a basis for future predictions. As an example, forest and nonforest cover changes were evaluated for two historical dates (1940 and 1972) and predicted 15 years ahead (1987). Results were examined by land allocation and land-use models discussed by McCarthy, et al., (1974) to determine the effects of land-use changes (urbanization) on forest cover resources in a selected study area (Clinton Quadrangle, Anderson County, Tennessee). Forest cover types recognized were as follows: hardwoods, pine-hardwoods, pines, cedar-hardwoods, and old fields (reverting to forest).

Cell size was 4.33 hectares ( 10.68 acres). Analysis of the 16,000-hectare $(38,000-$ acre) area showed a 33 percent decrease in forested land from 1940 to 1987

Areas reverting to forest (old fields) decreased 90 percent by 1972 and were virtually nonexistent by 1987 due to predicted land-use changes. Less than 1 percent ( $8 \mathrm{ha}$.) of the original area classed as old field ( $900 \mathrm{ha}$. ) were predicted to remain by 1987 (Figure 3). The study indicates that significant changes are occurring which affect the forest resources in this area and consequently, hydrological characteristics and potential wildlife habitat are also altered.

Dynamic analysis and evaluations such as these are possible through a data processing procedure that emphasizes geodetic registration of data.

\section{CONCLUSIONS}

Processing remotely sensed data and information from other sources for dimensional analysis of forest resources enhances the visual and statistical 
analysis tools used by the (forest) manager and planner. Registering cellular data by geodetic coordinates allows: (1) spatial or single variable analysis to provide areal summaries, (2) overlay or composite analysis to delineate homogeneous management units, and (3) temporal analysis to detect and predict effects over time. Furthermore, cell size is flexible and can be selected to meet the resolution needs of analysis effort.

\section{LITERATURE CITED}

Anderson, James R., E. E. Hardy, and J. T. Roach. 1972. "A Land-Use Classification System for Use with Remote Sensor Data." Geological Survey. Circular No. 671 .

Cox, T. L. and S. G. Weber. 1975. "Medium Scale Color Infrared Imagery Evaluation as a Data Source for Developing Intensive Management Plans." Presented at the Symposium on the Utilization of Remote Sensing Data in
Southeastern United States, University of Georgia, Athens, Georgia, January $29-30,1975$.

Durfee, R, C. "GRIDOT - An Automated Plotting Program to Produce Sampling Grids for Map Digitization." ORNLNSF-EP Report, Oak Ridge National Laboratory, Oak Ridge, Tennessee (in preparation).

McCarthy, M. M., R. C. Durfee, M. L. Newman, S. L. Yaffee, R. Betson, C. W. Craven, Jr., T. L. Cox J. Holbrook, D. D. Huff, and R. Strand. 1974. "Regional Environmental Systems Analysis: An Approach for Management." In: Proceedings, The First International Congress of Ecology, The Hague, Netherlands, September 8-14, 1974.

Stevens, A. R. 1973. "Land Cover Delineation Methods and Presentation Alternatives Applicable to the Tennessee River Watershed." In: Remote Sensing of Earth Resources, Vol. II. F. Shahrokhi (Ed.). University of Tennessee Space Institute 


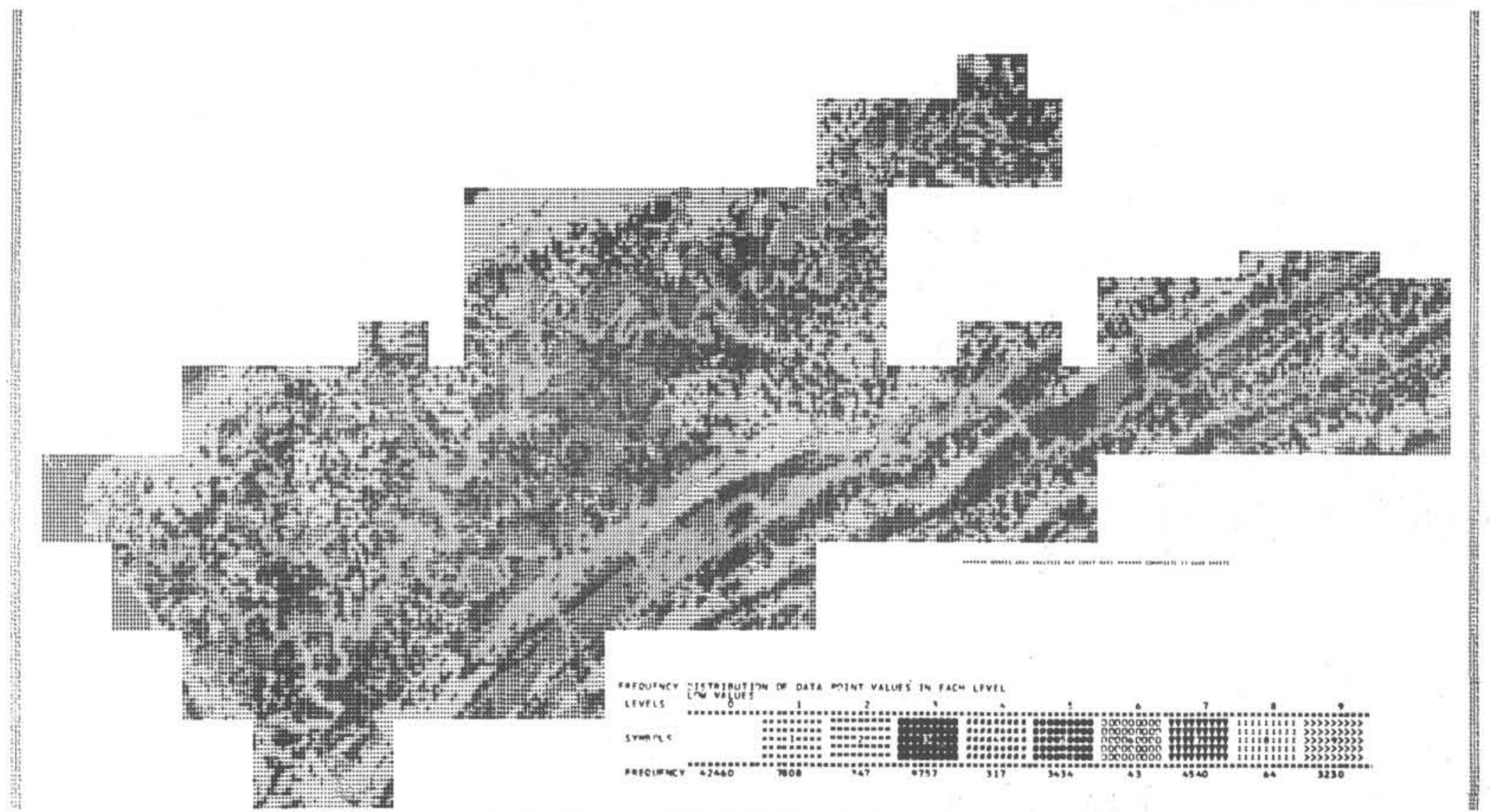

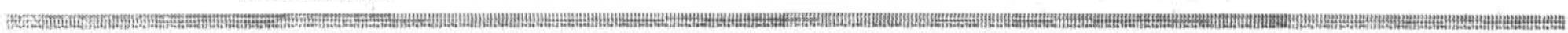

Leve1 Description

$\begin{array}{ll}1 & \text { Agriculture and Open } \\ 2 & \text { Old Field } \\ 3 & \text { Hardwood (> 75\% Hardwood) } \\ 4 & \text { Planted Pine ( } 75 \% \text { Planted) } \\ 5 & \text { Natural Pine (>75\% Pines) } \\ 6 & \text { Cedar Hardwoods } \\ 7 & \text { Mixed (<75\% Pine or Hardwoods) } \\ 8 & \text { Constructed Surface } \\ 9 & \text { Water }\end{array}$

FIGURE 1: Single variable analysis showing cover type distributions for the Norris Study Area using line printer display, 


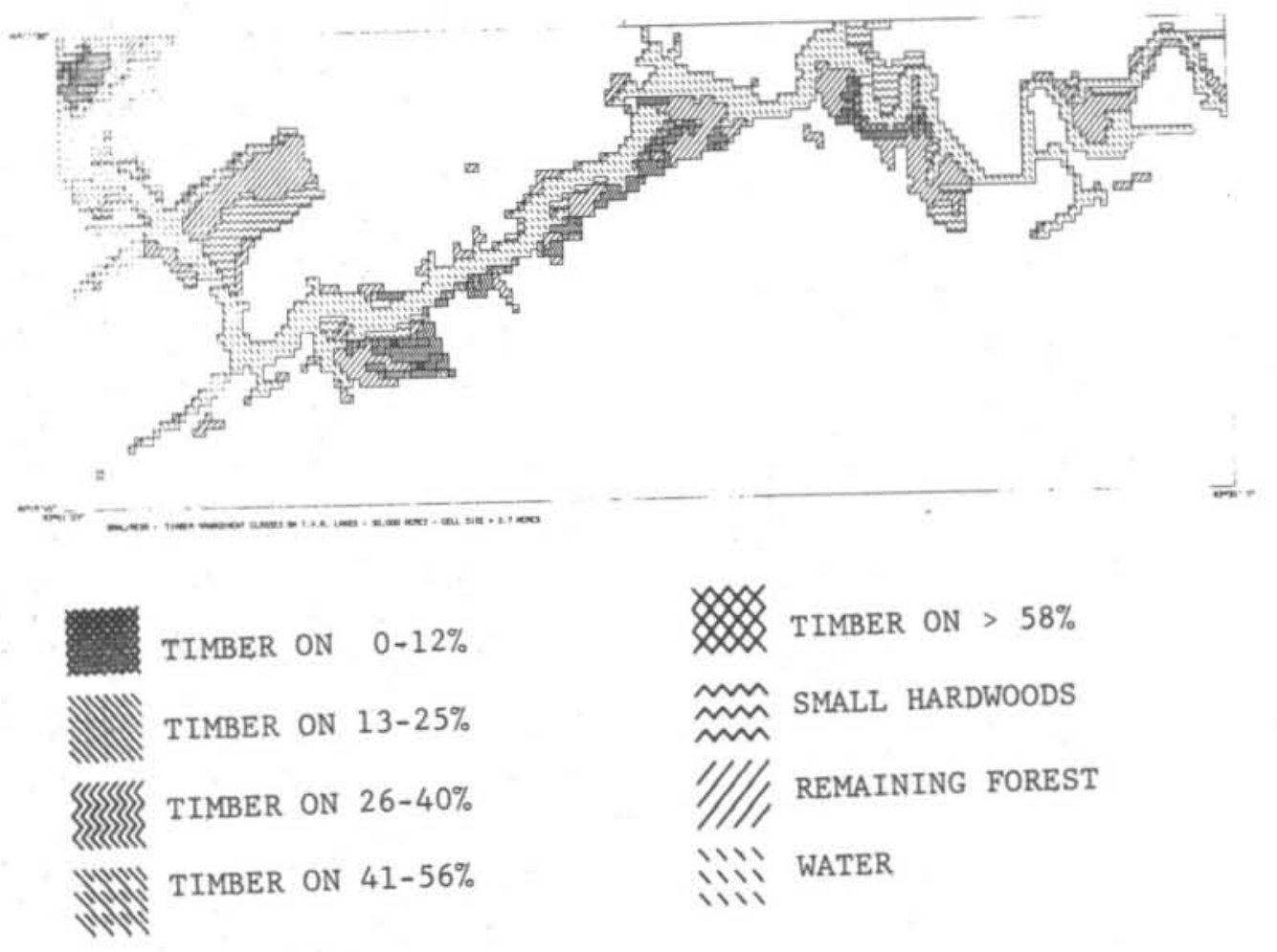

FIGURE 2: Overlay analysis delineating timber management classes on TVA lands using plotter display. 

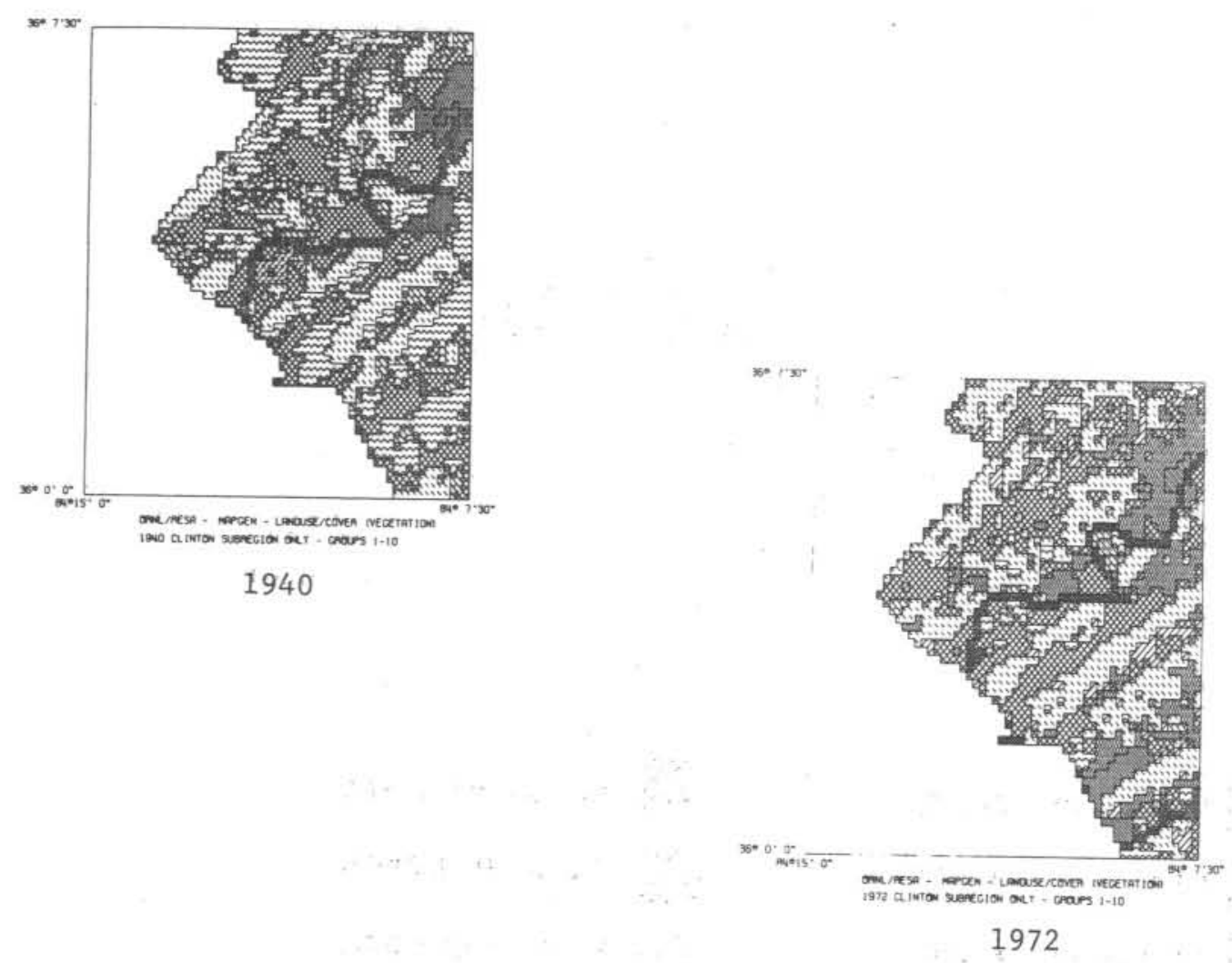

Water (Lake and River)

Urban and Built Up

Residential

Open and Other

Agricultural

․ㅏㅂ 01d Field

xxyxy Cedar Hardwood

끌 Pine Hardwood

U/l/, Pine

渠: Hardwood

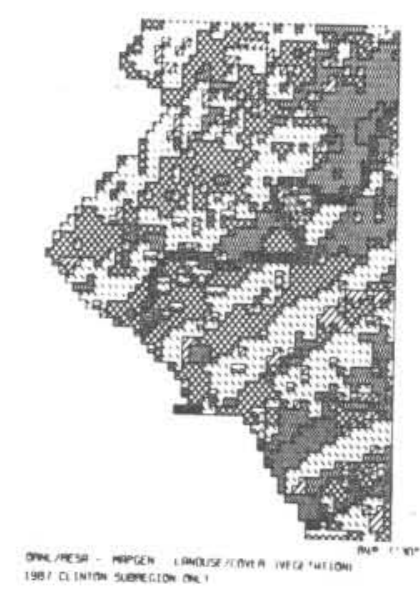

1987

FIGURE 3: Temporal analysis of land-use/cover changes for the Clinton subregion for three dates using historical and predicted data. 